\title{
Diet adjustments of maned wolves, Chrysocyon brachyurus (Illiger) (Mammalia, Canidae), subjected to supplemental feeding in a private natural reserve, Southeastern Brazil
}

\author{
Joaquim A. Silva ${ }^{1}$ \& Sônia A. Talamoni ${ }^{1,2}$ \\ ${ }^{1}$ Conservation, ecology and animal behaviour group, Post-graduate Programme in Vertebrate Zoology, Pontifícia \\ Universidade Católica de Minas Gerais. 30535-610 Belo Horizonte, Minas Gerais, Brasil. E-mail: quincass@hotmail.com \\ 2 Corresponding author. E-mail: talamoni@pucminas.br
}

\begin{abstract}
From the analysis of 230 scats, the diet of the maned wolves, Chrysocyon brachyurus (IIliger, 1815), was determined in a private natural reserve in southeastern Brazil in which ecotourism activities are developed and the animals are deliberately fed bovine meat. A total of 569 occurrences of food items were recorded, of which $56.8 \%$ were of animal origin and $29.1 \%$ of vegetal origin. Rodents, insects and birds added up to $35.8 \%$ of the occurrences, yet accounted for $68.5 \%$ of the total number of preys (277). Insects, however, had practically no importance $\mathbf{0 . 1 \% )}$ in the total estimated biomass consumed. Even though the fruit Solanum lycocarpum St.-Hil. is a common food item in the diet of the maned wolf, its occurrence in the diet at the Serra do Caraça Reserve was insignificant, accounting for only $4.8 \%$ of the total number of food item occurrences and $3.4 \%$ of the total estimated biomass consumption. Food items of anthropic origin and inorganic items (e.g., plastic) represented $14.1 \%$ of all occurrences, which shows that the animals are used to the presence of humans. Seasonal variations in consumption were found for $S$. Iycocarpum $\left(\chi^{2}=10,09 ; \mathrm{p}<0,001\right)$, for other fruits $\left(\chi^{2}=19,73 ; \mathrm{p}<0,001\right)$, and for reptiles $\left(\chi^{2}=15,56\right.$; $\left.p<0,001\right)$, all of which were more frequently eaten during the dry months. There was a significant correlation between the availability of small mammals and their consumption by the maned wolves $\left(r_{s}=0.59 ; p=0.041\right)$, yet the same was not observed for the fruits of $S$. lycocarpum $\left(r_{s}=0,101 ; p=0,754\right)$. Our findings stress the need for a better understanding of the effects of additional foods on the natural feeding habits of the maned wolf.
\end{abstract}

KEY WORDS. Chrysocyon brachyurus, diet, maned wolves, RPPN Serra do Caraça.

South-American canids are represented by a diverse group that diversified in the continent during the end of the Pliocene and beginning of the Pleistocene (BERTA 1987). The history of occupation of the Neotropical region by these animals started with distinct lineages, according to habitat availability (MCNAB 1989). The evolutionary lineage that occupied open-vegetation habitats gave origin, among others, to the maned wolf, Chrysocyon brachyurus (Illiger, 1815). A monotypic species and the biggest of South-American canids. In addition to its large size $(20-23 \mathrm{~kg})$, the maned wolf has distinct characteristics, well-developed limbs and ears, thick fur, and a peculiar color, that seem adapted to cursorial, crepuscular-nocturnal activities (Dietz 1984, Carvalho \& Vasconcellos 1995) in the tall, dense vegetation of grasslands (LANGGUTH 1975). The maned wolf is generalist/opportunistic in its diet (DiETz 1984, MotTA-Junior et al. 1996), which consists mainly of small mammals, fruits, insects, and birds. The feeding ecology of the species is currently being widely investigated (Barboza et al. 1994, Aragona \& SETZ 2001). However, it was only after MotTA-Junior et al. (1996) that data on the quantification of total biomass consumption, evaluation of diet seasonality and prey selection, and responses to variations in the abundance of trophic resources, (QUeIrolo \& MotTa-Junior 2000) became available.

In this work, the feeding ecology of the maned wolves was studied in the Serra do Caraça Natural Reserve, Catas Altas, Minas Gerais. The reserve is the site of a hotel and ecotourist activities, where individuals of this species, for more than twenty years now, have been fed on bovine meat, in addition to eating garbage left by visitors and have grown accustomed to the presence of humans. The purpose of this study was to determine whether the food habits of these individuals differ from those known for the species. 


\section{MATERIAL AND METHODS}

\section{Study area}

The Serra do Caraça Natural Reserve $(10.187,89$ ha) is located in the State of Minas Gerais in the southern portion of the Espinhaço range $\left(20^{\circ} 05^{\prime} \mathrm{S} ; 43^{\circ} 29^{\prime} \mathrm{W}\right)$. The region is formed by an mountain complex, that delimitates a zone of contact between the "Cerrado" (savannas) and the Atlantic Forest, in the south, and a zone of transition from "Cerrado" to Atlantic Forest to "Caatinga", in the north (Derby 1966, Giulietti \& Pirani 1988, GiulietTi et al. 1997). At altitudes ranging from 850 to $2070 \mathrm{~m}$ and with a climate marked by a rainy summer (OctoberMarch) and dry winter (April-September), the reserve shows various floristic formations that include seasonal semideciduous forests, "high-altitude fields", and "rupestrian fields". "Rupestrian fields" consist of grasslands surrounded by rock outcrops, as well as shrubs and small trees. Vegetation patches in different stages of ecological succession are present in the region, as a consequence of timber extraction and the "slashand-burn" practice used in the past.

The reserve represents a rich artistic, cultural, and historical heritage resulting from over two centuries of human occupation (ANDRADE 2000).

\section{Methods}

The diet of the maned wolves was determined by scat analysis. Scat search and collection was carried out monthly from May, 2000 to October, 2001. The scats were identified by their odor and deposition site, associated with animal tracks. Each scat sample was placed in a plastic bag and identified by date, location, site of deposition, and other pertinent information. To identify the remaining ingesta, the samples were soaked in water and then washed over a fine-mesh screen and dried in an oven at $60^{\circ} \mathrm{C}$, during $24 \mathrm{~h}$. The items were separated and grouped into categories for analysis. With the help of reference collections, remains of mandibles, teeth, hairs, bills, scales, chitins and other fragments were used to identify and count the number of individual prey items (MOTTA-JunIor et al. 1996, RAY 1998). The seeds were identified with the assistance of botanists. The known average number of seeds per fruit species was compared with the number of seeds in scats to estimate the number of fruits consumed and their biomass species obtained in the area (CASTRO et al. 1994). Analyses were made of the frequency of occurrence of the food items as a function of the total number of occurrences (DieTz 1984) and the minimum number of animal preys (MotTAJUNIOR et al. 1996, RAY 1998). Total biomass consumption was estimated on the basis of field-collected material, reference collections, and data from the literature (FonseCA et al. 1996, Motta-Junior et al. 1996, Marini et al. 1997).

To establish whether food consumption varies across the seasons of the year, the absolute frequency of the items found in the scats collected in the first 12 months of the study was compared, using the chi-square method (ZAR 1999). Variations in the consumption of small mammals and Solanum lycocarpum fruits - frequent items in the diet of the maned wolf (DIETz 1984, MotTa-Junior et al. 1996) - were investigated using Spearman's Rank correlation coefficient, to determine whether a functional response occurs to variations in seasonal abundance of such items (JAKSIC 1989).

The availability of small mammals ( $<1 \mathrm{~kg}$ in weight) was evaluated in two areas showing strong evidence of utilization by the maned wolves. Animal abundance was determined by the capture-mark-recapture method. Live traps $(21 \mathrm{~cm} \mathrm{x} 15 \mathrm{~cm}$ $\mathrm{x} 15 \mathrm{~cm}$ ) were set on ground level at $15 \mathrm{~m}$ intervals along $150 \mathrm{~m}$ lines separated by a distance of $20 \mathrm{~m}$, totalling 30 traps covering $1.6 \mathrm{ha}^{-1}$ in each area. During four nights in each month from July, 2000 to May, 2001, the traps were baited with a mixture of mashed bananas and peanut butter and checked in the following morning. The total capture effort was 2,880 trap-nights. Before releasing, records of the animals' biometric data were made. Voucher-specimens of each small mammal species were collected to aid in the identification of the material found in the scats.

Sampling of $S$. lycocarpum was performed in five areas measuring $100 \mathrm{~m} \times 5 \mathrm{~m}$, demarcated at $200 \mathrm{~m}$ distances on either side of a local road where there is a large concentration of such trees. Fifty individuals were marked and their fruiting phenology was determined each month, from November, 2000 to October, 2001, by direct counting of individual fruits and flowers.

\section{RESULTS}

The sampling of 230 scats was considered satisfactory, judging from the asymptotic curve of the items consumed, particularly from the $170^{\text {th }}$ sample onwards (Fig. 1), which corresponded to $73.5 \%$ of all samples collected. Pasty or watery scats were found monthly. Of all samples collected, $83.9 \%$ were found on rocks, $9.5 \%$ on a heap of crushed rock, $3.5 \%$ on reserve trails, $2.2 \%$ on an asphalt road, and $0.9 \%$ on top of termite mounds, with almost all samples (94.3\%) being associated with elevated sites of deposition.

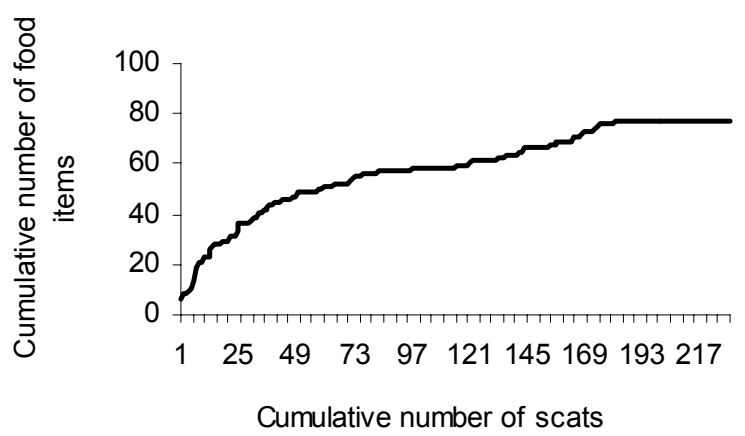

Figure 1. Cumulative number of food items found in scats of the maned wolves collected at Serra do Caraça Reserve, Minas Gerais, Brazil.

Seventy-two food items (Tab. I) were identified, of which $56.2 \%$ were of animal origin, $17.8 \%$ of vegetal origin, $13.7 \%$ inorganic items, and $12.3 \%$ were items of anthropic origin. "Anthropic items" corresponded to organic items taken from garbage cans and items deliberately offered to the animals. "Inorganic items" comprised items consumed accidentally together with garbage. "Other fruits" included 12 species and morphospecies of fruits.

Of the total food item occurrences recorded (569), 56.8\% were represented by animals, $29.0 \%$ by vegetal material, $9.1 \%$ by anthropic items, and $5.1 \%$ by inorganic material. Among the different items, grass was the most frequent (i.e., 19.5\%), 
Diet adjustments of maned wolves, Chrysocyon brachyurus...

Table I. Food items consumed by maned wolves at Serra do Caraça Reserve. Numerical data are: mean mass ( $\mathrm{g}$ ) of animals and fruits; occurrence; number of individual animals; estimated biomass (g). The animal body masses follow MOTTA-JÚNIOR et al. (1996), MARINI et al. (1997), reference collections of Departamento de Zoologia, Universidade Federal de Minas Gerais, Museu de Ciências Naturais da PUCMinas; Fundação Ezequiel Dias, Minas Gerais, and field-collected material.

\begin{tabular}{|c|c|c|c|c|}
\hline Animal items & Mass (g) & Occurrence & Number & Estimated biomass (g) \\
\hline \multicolumn{5}{|l|}{ Insects } \\
\hline Orthoptera (unknown) & 1.0 & 11 & 11 & 11.00 \\
\hline Acrididae (unknown) & 1.0 & 2 & 2 & 2.00 \\
\hline Hymenoptera (unknown) & 1.0 & 12 & 17 & 17.00 \\
\hline Formicidae (unknown) & 1.0 & 1 & 4 & 4.00 \\
\hline Coleoptera (unknown) & 1.0 & 14 & 16 & 16.00 \\
\hline Unidentified insect & 1.0 & 20 & 20 & 20.00 \\
\hline \multicolumn{5}{|l|}{ Anurans } \\
\hline Unidentified anuran & 120.0 & 1 & 1 & 120.00 \\
\hline \multicolumn{5}{|l|}{ Reptiles } \\
\hline Colubridae (unknown) & 209.0 & 1 & 1 & 209.00 \\
\hline Viperidae (unknown) & 209.0 & 1 & 1 & 209.00 \\
\hline Unidentified lizard & 68.2 & 7 & 7 & 477.40 \\
\hline Unidentified snake & 209.0 & 16 & 12 & $2,508.00$ \\
\hline \multicolumn{5}{|l|}{ Birds } \\
\hline Unidentified bird & 35.0 & 41 & 38 & $1,330.00$ \\
\hline Nonpasserines & 100.0 & 4 & 3 & 300.00 \\
\hline Anatidae (unknown) & $3,350.0$ & 1 & 1 & $3,350.00$ \\
\hline Cairina moschata (Linnaeus, 1758) & $3,350.0$ & 3 & 2 & $6,700.00$ \\
\hline Nothura maculosa (Wetmore, 1921) & 150.0 & 1 & 1 & 150.00 \\
\hline Aratinga leucophthalmus (Müller, 1776) & 120.0 & 1 & 1 & 120.00 \\
\hline Emberizoides sp. & 27.0 & 2 & 2 & 27.00 \\
\hline Egg shell & 10.0 & 1 & 1 & 10.00 \\
\hline \multicolumn{5}{|l|}{ Mammals } \\
\hline Unidentified small mammals & 22.2 & 49 & 31 & 687.90 \\
\hline Unidentified mammals & 230.0 & 5 & 4 & 920.00 \\
\hline Unidentified small marsupials & 21.8 & 2 & 2 & 43.60 \\
\hline Gracilinanus agilis (Burmeister, 1854) & 21.8 & 4 & 4 & 87.20 \\
\hline Didelphis albiventris (Lund, 1840) & 131.6 & 1 & 1 & 131.60 \\
\hline Dasypus sp. & $1,500.0$ & 9 & 7 & $10,500.00$ \\
\hline Unidentified small rodent & 22.2 & 9 & 6 & 133.40 \\
\hline Unidentified rodent & 380.0 & 6 & 5 & $1,900.00$ \\
\hline Akodon cursor (Winge, 1887) & 40.0 & 6 & 5 & 200.00 \\
\hline Bolomys lasiurus (Lund, 1841) & 46.0 & 15 & 11 & 506.00 \\
\hline Calomys tener (Winge, 1887) & 16.0 & 6 & 6 & 96,00 \\
\hline Oligoryzomys sp. & 13.0 & 7 & 7 & 91.00 \\
\hline Oryzomys subflavus (Wagner, 1842) & 94.0 & 13 & 9 & 846.00 \\
\hline Unidentified Echimidae & 230.0 & 3 & 3 & 690.00 \\
\hline Trichomys apereoides (Lund, 1839) & 230.0 & 1 & 1 & 230.00 \\
\hline Cavia aperea (Erxleben, 1777) & 384.0 & 18 & 11 & $4,224.00$ \\
\hline Galea spixii (Wagler, 1831) & 380.0 & 3 & 3 & $1,140.00$ \\
\hline
\end{tabular}

Revista Brasileira de Zoologia 20 (2): 339-345, junho 2003 
Table I. Continued.

\begin{tabular}{|c|c|c|c|c|}
\hline Animal items & Mass (g) & Occurrence & Number & Estimated biomass (g) \\
\hline Agouti paca (Linnaeus, 1766) & $8,227.0$ & 2 & 2 & $6,000.00$ \\
\hline Dasyprocta sp. & $2,800.0$ & 1 & 1 & $2,800.00$ \\
\hline Sylvilagus brasiliensis (Linnaeus, 1758) & 934.0 & 9 & 7 & $6,538.00$ \\
\hline Unidentified small carnivore & $1,580.0$ & 1 & 1 & $1,580.00$ \\
\hline \multicolumn{5}{|l|}{ Others } \\
\hline Unidentified vertebrates & 230.0 & 13 & 8 & $1,840.00$ \\
\hline \multicolumn{5}{|l|}{ Vegetal items } \\
\hline Diospyrus sp. & & 4 & & 3.00 \\
\hline Grass & & 111 & & 98.00 \\
\hline Myrtaceae (unknown) & & 3 & & 3.00 \\
\hline Psidium sp. & & 1 & & 2.90 \\
\hline Solanum lycocarpum St.-Hil. & & 27 & & $2,177.90$ \\
\hline Solanum sp. & & 1 & & 15.00 \\
\hline Syagrus sp. & & 2 & & 15.40 \\
\hline Baccharis sp. & & 1 & & 0.30 \\
\hline Convolvulaceae (unknown) & & 2 & & 4.00 \\
\hline Ilex sp. & & 9 & & 23.20 \\
\hline Ilex interregima Reissek & & 1 & & 0.30 \\
\hline Coix lacryma-jobi Linnaeus & & 1 & & 0.60 \\
\hline Unidentified seed & & 2 & & 0.50 \\
\hline \multicolumn{5}{|l|}{ Anthropic items } \\
\hline Prune & & 2 & & 1.70 \\
\hline Bean & & 1 & & 1.00 \\
\hline orange peel & & 1 & & 0.10 \\
\hline Papaya & & 9 & & 2.90 \\
\hline Watermelon & & 5 & & 0.50 \\
\hline Corn & & 1 & & 0.50 \\
\hline bovine meat & & 5 & & 9.00 \\
\hline Chicken & & 22 & & 79.20 \\
\hline Pig & $1,300.0$ & 6 & 4 & $5,200.00$ \\
\hline \multicolumn{5}{|l|}{ Inorganic items } \\
\hline Cotton & & 1 & & 0.10 \\
\hline Thread & & 1 & & 0.10 \\
\hline Nylon & & 1 & & 0.05 \\
\hline Toothpick & & 1 & & 0.20 \\
\hline Aluminium foil & & 8 & & 1.40 \\
\hline Stone & & 2 & & 1.80 \\
\hline Plastic & & 8 & & 1.20 \\
\hline Polyester & & 1 & & 0.01 \\
\hline Cigarette & & 1 & & 0.10 \\
\hline Glass & & 5 & & 0.90 \\
\hline Total & $27,026.80$ & 569 & 277 & $64,411.00$ \\
\hline
\end{tabular}

Revista Brasileira de Zoologia 20 (2): 339-345, junho 2003 

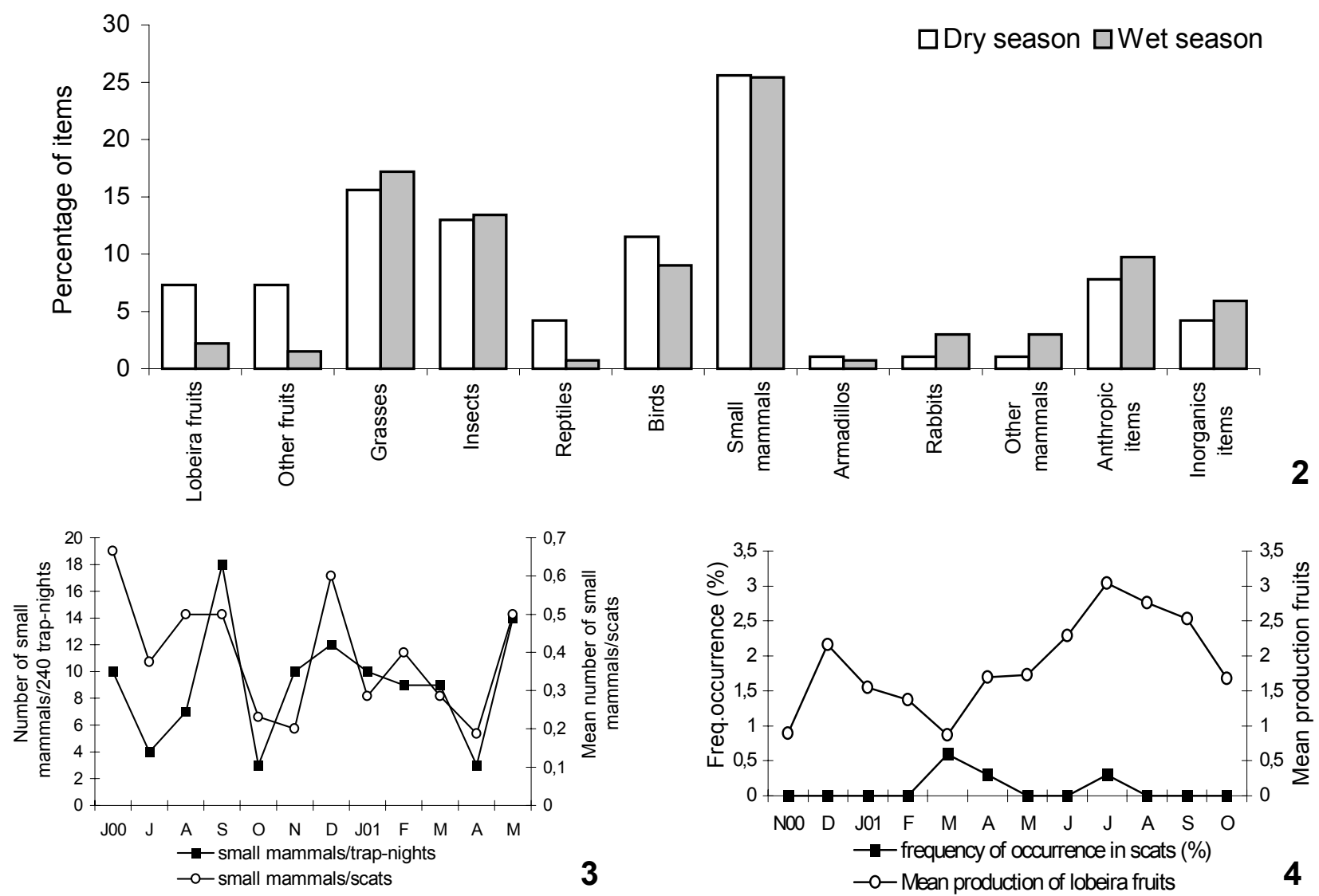

Figures 2-4. (2) Percentage of items found in scats collected in the dry and wet seasons during July, 2000 to May, 2001; (3) small mammal consumed by maned wolves according the availability of these resources; (4) frequency of occurrence of $S$. lycocarpum (lobeira fruits) in scats of maned wolves at Serra do Caraça Reserve, Minas Gerais, Brazil, and its availability at this habitat.

followed by rodents $(15.8 \%)$, insects $(10.5 \%)$, other mammals $(9.7 \%)$, and birds $(9.5 \%)$. All fruits together made up $9.6 \%$ of the total number of occurrences (Tab. II). Items of animal origin contributed with $88.1 \%(56,766 \mathrm{~g})$ of the total estimated diet biomass $(64,411 \mathrm{~g})$, with rodents being the predominant item (29.2\%). Vegetal items accounted for $3.7 \%(2,344 \mathrm{~g})$ of the total biomass, with S. lycocarpum (lobeira fruits) yielding 3.4\% (Tab. II). With the exception of $S$. lycocarpum, all other fruits recorded (Tab. I) had no fleshy, succulent pericarp, and were considered dry fruits. As for the animal items consumed, a total of 277 prey items were identified, with insects and rodents together accounting for $50.8 \%$ of the total items consumed.

About $58 \%$ of the samples were collected during the dry season and $41.6 \%$ during the rainy season. A significant correlation was found between rainy season and dry season consumption of $S$. lycocarpum $\left(\chi^{2}=10,0 ; p<0,001\right)$, other fruits $\left(\chi^{2}=19,7 ; p<0,001\right)$, and reptiles $\left(\chi^{2}=15,5 ; p<0,001\right)$, all of which were consumed mainly during the dry season. For all other items, no significant differences in seasonality were found (Fig. 2). A significant correlation was observed between variations in the abundance of small mammals and their consumption by the maned wolves $\left(r_{s}=0,59 ; p=0,041\right)$ (Fig. 3). However, the correlation between the consumption of $S$. lycocarpum fruits and their abundance in the reserve was not significant $\left(r_{\mathrm{s}}=\right.$ 0,101; $\mathrm{p}=0,754$ ) (Fig. 4).

\section{DISCUSSION}

Studies on the influence of human activities on the feeding behaviour of neotropical canids living in conservation units are scarce. SimonetTi (1986), analysing the diet of Pseudalopex culpaeus (Molina, 1782), observed an increased consumption of rabbits Oryctolagus cuniculus (Linnaeus, 1758) (19.7\% in 1976 and $48 \%$ in 1984), following their introduction in Los Dominicos, Chile. In Brazil, although Aragona \& Setz (2001) were the first to describe the diet of C. brachyurus in an area subject to tourism activities - the Ibitipoca State Park, State of Minas Gerais - no evidence of diet changes was recorded. Since deliberate feeding of the maned wolves has become a tourist attraction in the Serra do Caraça Reserve, the animals have often sought out for garbage cans.

As concerns animal items, similarities were found between the diet of the animals in this work and that of maned wolves living in regions characterized by "campos limpos" (open fields)

Revista Brasileira de Zoologia 20 (2): 339-345, junho 2003 
and "cerrados" (Dietz 1984, MotTA-Junior et al. 1996), where no anthropic activity occurs. On the other hand, our results showed some peculiarities that may be due to the habitats found in the Serra do Caraça Reserve (high-altitude fields and rupestrian fields) and the conditions the maned wolves are subjected to. The larger number of scats found in the dry season may be related to their sites of deposition - rock outcrops exposed in the midst of vegetation - making it easier for the scats to be washed away in the rainy period. The increased activity of coprophagous insects during the rainy period may also contribute to a lower number of scats during this time of the year (Dietz 1984). The presence of scats on top of termite mounds (cf. Dietz 1984) was seldom recorded in the Serra do Caraça Reserve, probably because of the rarity of this structure in that area.

The appearance of the scats also differed from that described by DieTz (1984), who reported scats with a diameter of 3.0 to $4.5 \mathrm{~cm}$. The scats found by us were smaller and their pasty and/or watery consistency suggested a picture of diarrhea. Although grass was a highly frequent item throughout the period of this study, its biomass and nutritional value was apparently unimportant. It could have been ingested accidentally together with prey, or intentionally consumed (DiETZ 1984), as it is known to help in the expelling of food remains and intestinal parasites (CARVAlHo \& VASCONCELlos 1995). Our results seem to corroborate this assumption, as the occurrence of grass in watery scats suggests it is consumed at times of altered intestinal function. Contrary to what is reported in other studies (DieTz 1984, ARAgona \& Setz 2001), the estimated biomass consumption of insects was irrelevant. Of the items of animal origin, rodents were of major importance in the diet of SouthAmerican canids (Langguth 1975). According to Dietz (1984), dissemination of the maned wolves in the continent at the end of the Pleistocene was simultaneous with the radiation of cricetid rodents, suggesting a long-standing predator-prey relationship. Our findings confirm the relevance of this food item, due to its frequent occurrence and participation in total biomass consumption by the maned wolves. However, our results differ from those reported by MotTa-Junior et al. (1996), and MotTa-Junior (2000), whom reported armadillos as the largest portion of the total biomass consumption. The preying of domestic duck Cairina moschata (Tab. I), as present in three scats, can be attributed to the fact that this bird is raised on a lagoon close to the Serra do Caraça Reserve hotel. No other domestic animal item was found in the scats, which seems to conflict with the belief entertained by farmers that the species is associated with domestic animal consumption.

A diet composed of equal proportions of vegetal and animal items, including high proportions of fruits, has been previously reported for the maned wolves (DiєTz 1984, MоттAJunior et al. 1996, MotTA-Junior \& MARTINs 2002). The minor participation of vegetal items in our study, including $S$. lycocarpum fruit, may be due to: (1) the relative scarcity of $S$. lycocarpum in most of the study area, particularly at altitudes over $1,200 \mathrm{~m}$, where the maned wolves are most frequently seen; (2) to the ingestion of meat offered to the animals daily by the Reserve's managers. On the other hand, the absence of $S$. lycocarpum in the diet of the animals may be deleterious to their health, as this resource, in addition to supplying water and carbohydrates, is rich in fibers and may control parasitic infections (COURTENAY 1994).
Table II. Diet of the maned wolves at Serra do Caraça Reserve represented by categories of food items found in scats collected during May, 2000 to October, 2001. Values in brackets are percentages.

\begin{tabular}{lrrrrrr}
\hline \multicolumn{1}{c}{ Food items } & \multicolumn{2}{c}{ Occurrence } & Number & \multicolumn{3}{c}{ Mass (g) } \\
\hline $\begin{array}{l}\text { Solanum lycocarpum } \\
\text { fruits }\end{array}$ & 27 & $(4.8)$ & & $2,177.90$ & $(3.4)$ \\
Other fruits & 27 & $(4.8)$ & & 68.20 & $(0.1)$ \\
Grass & 111 & $(19.5)$ & & 98.00 & $(0.2)$ \\
\hline Total vegetal & 165 & $(29.1)$ & & & $2,344.10$ & $(3.7)$ \\
\hline Insects & 60 & $(10.5)$ & 71 & $(25.6)$ & 71.00 & $(0.1)$ \\
Anura & 1 & $(0.2)$ & 1 & $(0.4)$ & 120.00 & $(0.2)$ \\
Lizards & 7 & $(1.2)$ & 7 & $(2.5)$ & 477.40 & $(0.7)$ \\
Snakes & 18 & $(3.2)$ & 14 & $(5.0)$ & $2,926.00$ & $(4.5)$ \\
Birds & 54 & $(9.5)$ & 49 & $(17.7)$ & $11,987.00$ & $(18.6)$ \\
Armadillos & 9 & $(1.6)$ & 7 & $(2.5)$ & $10.500,00$ & $(16.3)$ \\
Rabbits & 9 & $(1.6)$ & 7 & $(2.5)$ & $6,538.00$ & $(10.1)$ \\
Marsupials & 7 & $(1.2)$ & 7 & $(2.5)$ & 262.40 & $(0.4)$ \\
Rodents & 90 & $(15.8)$ & 70 & $(25.2)$ & $18,856.40$ & $(29.3)$ \\
Other mammals & 55 & $(9.7)$ & 36 & $(13.0)$ & $3,187.90$ & $(5.0)$ \\
Unknown & 13 & $(2.3)$ & 8 & $(2.8)$ & $1,840.00$ & $(2.8)$ \\
$\quad$ vertebrates & 323 & $(56.8)$ & & $56,766.10$ & $(88.1)$ \\
\hline Total animal & 52 & $(9.1)$ & & & $5,294.90$ & $(8.2)$ \\
\hline Anthropic items & 59 & $(5.0)$ & & 5,90 & $(0.0)$ \\
Inorganic items & 29 & $(100.0)$ & $277(100.0)$ & $64,411.00$ & $(100.0)$ \\
\hline Total & 569 & & & &
\end{tabular}

A smaller total estimated biomass consumption $(64,411$ $\mathrm{g}$ for 230 scat samples) was recorded in the present study, as compared to that reported by MOTTA-Junior et al. (1996) and MotTA-Junior (2000) (73, $483 \mathrm{~g}$ for 105 scat samples, and 100, $154 \mathrm{~g}$ for 191 scats, respectively). These discrepancies may be due to the different methods used, particularly for food item identification and biomass estimation. Also, one would expect that our animals, being satiated with the meat received daily, will show less hunting activity, an assumption that will have to be confirmed. On the other hand, the real contribution of bovine meat to the animals' diet could not be ascertained. Once ingested, this food item appears to be totally degraded in its passage through the digestive tract.

Contrarily to previous reports (DiETz 1984, MotTa-Junior et al. 1996), no seasonal influence on the diet of the maned wolves was observed, although a few items were consumed only in the dry season, which is in agreement with the findings of ARAGONA \& SETZ (2001). No functional response to the abundance of $S$. lycocarpum was observed, even though the occurrence of this food item in the scats coincided with the period of greater abundance of this fruit.

Our findings in the Serra do Caraça Reserve point to the need for a better understanding of the effects of the supply of artificial foods on the natural feeding habits of the maned wolf. 


\section{ACKNOWLEDGEMENTS}

We thank H.P. Godinho, R.J. Young, J.C. Motta-Junior, E.L.A. Monteiro-Filho and F.D. de Avila Pires for critically reading the manuscript. H. Alvarenga helped in identifying birds, G. B. Mahecha identified some remains, J. R. Stehmann identified the fruits. The Caraça Reserve keepers provided us with all facilities to study. Financial support was provided by FIP - PUC Minas and FAPEMIG.

\section{REFERENCES}

Andrade, M.G. 2000. A educação exilada, Colégio do Caraça. Belo Horizonte, Editora Autêntica, 214p.

Aragona, M. \& E.Z.F. Setz. 2001. Diet of maned wolf, Chrysocyon brachyurus (Mammalia: Canidae), during wet and dry seasons at Ibitipoca State Park, Brazil. Journal of Zoology, London, 254: 131-136.

Barboza, P.S.; M. E. Allen; M. Rodden \& K. Pojeta. 1994. Feed intake and digestion in the maned wolf (Chrysocyon brachyurus): consequences for dietary management. Zoo Biology, Williamstown, 13: 375-381.

Berta, A. 1987. Origin, diversity, and zoogeography of the South American Canidae. Fieldiana Zoology, New Series, Chicago, 39: 455-471.

Carvalho, C.T. \& L.E.M. Vasconcellos. 1995. Disease, food and reproduction of the maned wolf - Chrysocyon brachyurus (Illiger) (Carnivora, Canidae) in southeast Brazil. Revista Brasileira de Zoologia, Curitiba, 12: 627-640.

Castro, S.A.; S.I. Silva; P.L. Meserve; J.R. Gutierrez; L.C. Contreras \& F.M. JAKSIC. 1994. Frugivoria y dispersión de semillas de pimiento (Schinus molle) por el zorro culpeo (Pseudalopex culpaeus) en el Parque Nacional Fray Jorge (IV Región, Chile). Revista Chilena de Historia Natural, Santiago, 67: 169176.

Courtenay, O. 1994. Conservation of the Maned Wolf: Fruitful relations in a changing environment. Canid News, Oxford, 2: 41-43.

Derby, O.A. 1966. The Serra of Espinhaço, Brazil. Journal of Geology, Chicago, 14: 374-40.

DiETZ, J.M. 1984. Ecology and social organization of the maned wolf (Chrysocyon brachyurus). Smithsonian Contributions to Zoology, Washington, D.C., 392: 1-51.

Fonseca, G.A.B.; G. Herrmann; Y.L.R Leite; R.A. Mittermeier; A.B. RYLANDS \& J.L. PATTON. 1996. Lista anotada dos mamíferos do Brasil. Belo Horizonte, Conservation International, Fundação Biodiversitas, 38p.

Giulietti A.M. \& J.R. Pirani. 1988. Patterns of geographic distribution of some plant species from the Espinhaço Range, Minas Gerais and Bahia, Brazil, p. 39-69. In: P.E. VANZoLINI \&
W.R. Heyer (Eds). Proceedings of a workshop on Neotropical distribution patterns. Rio de Janeiro, Academia Brasileira de Ciências.

Giulietti, A.M.; J.R. Pirani \& R.M. Harley. 1997. Espinhaço Range region, Eastern Brazil, p. 397-404. In: S. D. DAvis; V.H. Heywood; O. Herrera-MacBryde; J. Villa-Lobos \& A.C. HamilTON (Eds). Centres of plant diversity, a guide and strategy for their conservation. Oxford, Information Press, 562p.

JAKSIC, F.M. 1989. Opportunism vs. Selectivity among carnivorous predators that eat mammalian prey: a statistical test of hypotheses. Oikos, Lund, 56: 427-430.

LangGuth, A. 1975. Ecology and evolution in the South American canids, p. 192-206. In: M.W. Fox (Ed.). The wild canids: their systematics, behavioral ecology and evolution. New York, Van Nostrand Reinhold Co., 508p.

Marini, M.A.; J.C. Motta-Junior; L.A.S. Vasconcellos \& R.B. CaVALCANTI. 1997. Avian body masses from the cerrado region of central Brazil. Ornitologia Neotropical, Athens, 8: 9399.

MCNAB, B.K. 1989. Basal rate of metabolism, body size, and food habits in the order Carnivore, p. 335-354. In: J.L. GiTTLEMAN (Ed.). Carnivore behavior, ecology and evolution. Knoxville, University of Tennessee Press, 620p.

MotTA-Junior, J.C. 2000. Variação temporal e seleção de presas na dieta do lobo-guará, Chrysocyon brachyurus (Mammalia: Canidae) na Estação Ecológica de Luís Antônio, SP, p. 331346. In: J.E. SANTOS \& J.S.R. Pires (Eds). Estudos Integrados em Ecossistemas. Estação Ecológica de Jataí. São Carlos, Rima Editora, 346p.

Motta-Junior, J.C. \& K. Martins. 2002. The frugivorous diet of the maned wolf, Chrysocyon brachyurus, in Brazil: ecology and conservation, p.291-303. In: D.J. LeVEY; W.R. SILVA \& M. GALETTI (Eds). Seed dispersal and frugivory: ecology, evolution and conservation. Walligford, CABI Publishing, 544p.

Motta-Junior, J.C.; S.A. Talamoni; J.A. Lombardi \& K. Simokomaki. 1996. Diet of the maned wolf, Chrysocyon brachyurus, in central Brazil. Journal of Zoology, London, 240: 277-284.

Queirolo, D. \& J.C. MotTa-Junior. 2000. Possível influência das mudanças da paisagem no Parque Nacional da Serra da Canastra-MG na dieta do lobo-guará, (Chrysocyon brachyurus), p. 706-714. In: Anais do II Congresso Brasileiro de Unidades de Conservação. Campo Grande.

RAY, J.C. 1998. Temporal variation of predation on rodents and an shrews by small African forest carnivores. Journal of Zoology, London, 244: 363-370.

Simonetti, J.A. 1986. Human-induced dietary shift in Dusicyon culpaeus. Mammalia, Paris, 50: 406-408.

ZAR, J.H. 1999. Biostatistical Analysis. Upper Saddle River, Prentice-Hal, $4^{\text {th }}$ ed., 663p.

Received in 09.I.2003; accepted in 27.V.2003.

Revista Brasileira de Zoologia 20 (2): 339-345, junho 2003 